Basile Baudez

\title{
THE UNIVERSITY: AN ARCHITECTURAL TYPE?
}

The programme of the university is essentially ambivalent: laboratory and palace, equipment and monument. A university does not follow the same rules of economy as elementary schools. Each institution seems to require its own programme. If the university as an institution dates back to the Middle Ages, it has never really acquired a specific idiom of its own, which is demonstrated by Nikolaus Pevsner's 1976 seminal book on the history of architectural type ${ }^{1}$. However, this does not prevent us from trying to understand the reasons why architects and institutional clients have never succeeded in establishing a specific and proper architectural form for the university.

Focusing on the French case, and particularly Paris, we aim to examine the architectural history of the university from the Middle Ages to the end of the eighteenth century, by defining one of its main feature, the amphitheatre-type lecture hall, and analysing the first projects for modern higher educational buildings at the turn of the $18^{\text {th }}$ and $19^{\text {th }}$ centuries.

Higher education was first acquired during the Middle Ages in the cloisters of cathedrals and abbeys when the Church replaced the Gallo-Roman civic and private school network, which was destroyed by the fall of the Roman Empire. In the thirteenth century, during the

DOI: https://doi.org/10.12697/BJAH.2018.15.03

1 Nikolaus Pevsner, A History of Building Types (Princeton: Princeton University Press, 1976). 
increase in urban life that occurred during the so-called medieval Renaissance, new structures, called colleges, were created within the town walls.

They were comprised of private houses which provided accommodations for the students who came to attend the lectures of renowned masters. Most of these institutions were provided by princes in order to help poor students who could not afford housing in the crowded and expensive Left Bank in Paris, where most of the convents were located. ${ }^{2}$ This also applies to the Sorbonne: on 21 October 1250, Queen Blanche of Castilla, mother of Saint Louis, gave a house near the baths of Cluny to Master Robert de Sorbon, which was to be used to house needy students from his northern province. Four years later the college was officially founded and the masters of theology started teaching inside the house. In the decades that followed, the Left Bank saw the number of private teaching masters multiple based on the model of the artisan world, in which apprentices lived in their master's house and learned their trade. Therefore, these buildings that were initially used for higher education were indistinguishable from other private houses. All the teaching master needed was a room of a certain size along with a few annexes and bedrooms. The furnishings were quite spare: in Bologna in the $14^{\text {th }}$ century school of Giovanni d'Andrea, there were backless chairs, a podium and a few desks for the students. ${ }^{3}$ The University of Leuven in 1426 bought a house where it remained until 1797, and in 1366, the Carolinum of Prague, installed its first students and classes in a private house.

But at the end of the Middle Ages, some changes had occurred in the Parisian university system. The faculties of the masters continued to hold assemblies in churches. For example, around 1300, the arts faculty met in the Church of Saint-Julien-le-Pauvre between the cathedral and the river Seine, and the law and medicine faculty in the Church of the Mathurins. However, the university soon started to buy separate buildings for these meetings. Pressured by the public authorities, these gathering places slowly became places of learning. Inside a house built in 1436 in the Normand town of Caen to house

2 Aurélie Perraut, L'architecture des collèges parisiens au Moyen Age (Paris: Presses de l’Université Paris-Sorbonne, 2009).

3 Léo Moulin, La vie des étudiants au Moyen Âge (Paris: Albin Michel, 1991), 212-213. 
the meetings of the university's teaching faculty, there was a large room on the ground floor for the faculty of arts and the faculty of law. Another room on the first floor was devoted to the faculties of theology and medicine, and a small library was located on the second floor. ${ }^{4}$ Konrad Rückbrod had summarised the three stages of this phenomenon: first, one or several masters taught in a rented or donated private house; then the masters started to meet in separate buildings; and at the end of the $14^{\text {th }}$ century, the two functions were combined to form proper schools. ${ }^{5}$ In Paris, for example, the faculty of medicine bought a house on the Rue de la Bûcherie in 1369. In 1454, Jacques Despars, the royal physician, donated the money to build a separate house. On the ground floor, which consisted of a large room divided by two pillars, students listened to lectures and defended their thesis. On the upper floor, the university faculty members met. In 1508, a small botanical garden was even installed in the courtyard. ${ }^{6}$ At the nearby Collège des Bernardins, a single long vaulted room divided into two naves by a series of pillars performed the two functions based on the architectural model of the convent refectory.

The facades of the houses included a combination of elements taken from non-descript private houses and also some religious and political ornamentation. These characteristics were consistently maintained in subsequent centuries. The Scots College in Paris, which was established in 1333 by the Bishop of Murray to house Scottish students who came to attend classes at the Sorbonne, was rebuilt in 1662. The facade on Rue du Cardinal-Lemoine is particularly elegant but there is no sign of the educational purpose of the building. The religious element is even more discreet, hidden from the street into the backyard. The Collège de Sorbonne, the most prestigious of all, differs from this traditional model. The different components of the institution are clearly identifiable from the street, as the chapel is a free-standing building visible to passersby. There were two other large buildings: one housing the library; and the other classrooms,

4 Nikolaus Pevsner, 'Universities Yesterday', The Architectural Review, CXXII (729) (Oct. 1957), 235-239.

5 Konrad Rückbrod, Universität und Kollegium. Baugeschichte und Bautyp (Darmstadt: Wissenschaftliche Buchgesellschaft, 1977).

6 Jules Perrin, 'Les anciennes Écoles de Médecine de la rue de la Bûcherie et la Maison des Étudiants', L'Architecture, 25 July 1921, 3. 
as well as dormitories for the poor students and apartments for the masters and rich pupils. In 1635, when Cardinal de Richelieu, Chief Minister of King Louis XIII, provided a large sum to rebuild the entire complex, his architect Jacques Lemercier made sure to situate the chapel and other buildings around a courtyard. ${ }^{7}$ The dual function of the chapel is perfectly expressed by its two-sided facades: the one facing the college courtyard is intended for the faculty and the students; the one facing the street for those wishing to visit the founder's funerary monument sculpted by François Girardon in 1694. Richelieu's successor, Cardinal Jules Mazarin followed in his mentor's footsteps at the Collège des Quatre-Nations, which he created in 1661 for the students of the four French provinces recently annexed by the kingdom. Architect Louis Le Vau designed a large chapel visible from the street and the opposite side of the river, where the Louvre Palace is located, and organised the library and the other rooms in the buildings around an inner courtyard. ${ }^{8}$ Mazarin, like Richelieu, had his monument in the chapel sculpted by Antoine Coysevox. ${ }^{9}$ The difference with the Sorbonne lies in the shape of the chapel. The building has a central circular rotunda that enables the faculty and students to sit on benches arranged in circles. This example illustrates the synthesis between the medieval tradition of church meetings and the new type of hall, which was borrowed from the medical world - the amphitheatre-type lecture hall.

During the fifteenth century, the university colleges gradually adopted new teaching methods. Lectures, in which the professor explained and demonstrated texts to a listening and seated audience, started to replace the medieval dispute and commentaries with dialogues being the norm. Therefore, a good view of the teacher became essential in these teaching spaces, whereas only the acoustics had been important before. The long room divided by pillars started

7 Alexandre Gady, Jacques Lemercier, architecte et ingénieur du Roi (Paris: Éditions de la Maison des sciences de l'homme, 2005), 309-322.

8 Le Palais de l'Institut: du collège des Quatre-Nations à l'Institut de France, ed. by Jacques Babelon (Paris: Nicolas Chaudun, 2005). Alexandre Cojannot, 'Sans lieu ni maître. La genèse du collège Mazarin à la lumière des dessins précoces de Louis Le Vau', Le dessin instrument et témoin de l'invention architecturale, ed. by Claude Mignot (Paris: L'Echelle de Jacob, 2014), 63-72.

9 Claire Mazel, 'Un tombeau d'exception. Comparaison des monuments funéraires de Richelieu à la Sorbonne et de Mazarin au collège des Quatre-Nations', Richelieu patron des arts, ed. by Jean-Claude Boyer, Barbara Gaehtgens, Bénédicte Gady (Paris: Editions du Passage, 2009), 175-200. 
to feel particularly inadequate for the new situation. Therefore, a new architectural type, in which an entire audience could easily see and hear the professor was expected. The solution came from the medical world. The birth of the amphitheatre-type lecture hall is linked to the development of anatomy as a science and the practice of dissection as advocated by humanist surgeons and anatomists such as Vesalius. Surgeons had to fight against the prejudices of the Church in the early $16^{\text {th }}$ century. Vesalius was the first to design amphitheatres for teaching purposes in Bologna and Padua. At first, they were temporary structures, but they soon became permanent buildings, like the one in Padua which was completed in 1594 and became the model amphitheatre. ${ }^{10}$ The wooden structure, which was circular in shape with tiers on a steep slope, was based on the model of the Odeon in Rome. The students and spectators had a view from above and were located at an equal distance from the lecturer, who stood on the floor near the dissection table. After Padua, a number of anatomical theatres were built in Europe: in Leyden in 1612, in Bologna in 1637, where Antonio Paolucci (known as il Levanti) built a rectangular wooden structure with benches installed on the inclines on each of the sides. In London, Robert Hooke published the plans of the theatre that he built for the Royal College of Physicians in 1674. It was the first freestanding structure of its kind.

An anatomical theatre for the Paris community of surgeons was built in 1616 and for the doctors in 1620. The surgeons rebuilt their teaching space after 1691. The architect Charles Joubert erected a large and modern amphitheatre with a dome visible from the street on a piece of land rented to the Cordeliers. ${ }^{11}$ Unlike the early Italian examples, most of the amphitheatres, built in Paris in the $17^{\text {th }}$ century, were illuminated. Their octagonal plan allowed for a good distribution of the spectators while the professor had his back to the entry and faced the audience. In the early $18^{\text {th }}$ century, Robert de Cotte, the Chief Architect of the King, designed a new theatre for the faculty of medicine with a rectangular plan. But

10 Il teatro anatomico, storia e restauri, ed. by Camillo Semenzato, Vittorio Dal Piaz (Padova: Università degli Studi di Padova, 1994).

11 Pierre-Louis Laget, 'L'amphithéâtre d'anatomie', Chalgrin et son temps: architectes et architecture de l'Ancien Régime à la Révolution, ed. by Basile Baudez, Dominique Massounie (Bordeaux: Blake \& Co, 2016), 188. 
due to the lack of funding, it never saw the light of day. ${ }^{12}$ Nevertheless, the circular plan was universally adopted in the mid- $18^{\text {th }}$ century, and this was still the case at the beginning of the next century when Johann Wilhelm Krause designed the anatomical theatre for the University of Tartu..$^{13}$ However, in 1775, a lavish new building designed for the School of Surgery opened in Paris. ${ }^{14}$ Designed by Jacques Gondouin, a young architect who had just returned from Rome, it introduced a new type of main lecture hall. Instead of adopting the octagon, the circle or the rectangle, Gondouin chose to design his main theatre in the shape of a semicircle. He was inspired by the Odeon in Rome, which he studied while he was a royal pensionnaire at the French Academy in Rome between 1761 and 1766. There, with other architects, painters and sculptors who spent a lot of time with Gian Battista Piranesi, he studied ancient Roman architecture and participated in archaeological digs. Gondouin's Paris amphitheatre could seat 1,400 people. It had more space than needed for the spectacle of dissection, and the size indicates that it was used for lectures to surgery students. Indeed, behind the main hall, one can find a smaller room for proper dissection demonstrations. For the first time, the School of Surgery provides the model for the university lecture hall as we know it today. But even before the foundation of the first modern universities in France, it was adopted by politicians for their assembly halls.

At the start of the Revolution, doctor Jacques Guillotin, a professor at the Paris School of Surgery, suggested to Jacques Alphonse de Gisors and Emmanuel-Chérubin Leconte, the architects of the young National Assembly, that a semicircle should be employed rather than the medieval system of the British Parliament comprised of a rectangular space with rows of benches facing each other. ${ }^{15}$ At the same time, their colleague Charles De Wailly was also designing a

12 Paris, Archives nationales, G7 1728 (1712-1715), letter dated 21 September 1713 by d'Argenson. Quoted by Pierre-Louis Laget, 'L'amphithéâtre d'anatomie', op. cit., 192.

13 Juhan Maiste, Kadi Polli, Mariann Raisma, Alma Mater Tartuensis. Das Anatomische Theater (Tartu: Eesti Keele Sihtasutus, 2003).

14 Pierre-Louis Laget, 'Du Collège Saint-Côme au Temple d'Esculape, un monument royal dédié à l'art et science de chirurgie', Paris, capitale des arts au XVIIIe siècle, ed. by Daniel Rabreau (Bordeaux: William Blake \& Co, 1997), 149-165; Denis Bilodeau, 'Types et historicisme: l'Ecole de Chirurgie de Jacques Gondouin et l'émergence d'une conception généalogique de l'architecture en France au XVIIIe siècle', L'architecture, les sciences et la culture de l'histoire au XIXe siècle (Saint-Etienne: Publications de l'Université de Saint-Etienne, 2001), 131-143.

15 Henri Pigaillem, Le Docteur Guillotin, bienfaiteur de l'humanité (Paris: Pygmalion, 2004). 
political assembly hall in the shape of a semicircle. It was based on the research related to acoustics and visibility that he had conducted while designing the modern Parisian theatre of the Comédie Française a few years earlier. ${ }^{16}$ When adopting the semicircular shape, the architects moved the teacher's catedra from the floor near the dissection table, to a podium so he could be seen and heard clearly by the entire audience. This last feature gave birth to the modern university lecture hall. ${ }^{17}$ But are there any other features, typical of higher education buildings that can define the university as an architectural type? To answer this question, I propose to analyse four newer higher education projects designed in Paris in the late $18^{\text {th }}$ century. ${ }^{18}$

The second half of the $18^{\text {th }}$ century corresponds to a new institutional moment. The university had experienced a steady decline and was rivalled by new institutions of higher learning and professional schools, which were more efficient and innovative in their pedagogical approaches. The triumph of the surgeons over the physicians was achieved by Jacques Gondouin's School of Surgery, which immediately became the model for higher education architecture. It is at the margins of the university, in the faculties that were scattered in the Quartier Latin (law at the Clos-Bruneau, medicine on the Rue de la Bûcherie, theology at the Sorbonne) that the most innovative educational institutions emerged in the second half of the century. The main difference compared to the traditional model was the fact that these institutions would be devoted exclusively to pedagogy and classrooms and not include student lodgings. It is during the last twenty years of the Ancien Régime that the architectural type of the university was defined in France, by three realised projects and an unrealised one: the Law Schools by Jacques-Germain Soufflot built between 1763 and 1774; the aforementioned School of Surgery by Jacques Gondouin built

16 Daniel Rabreau, Monique Mosser, Charles De Wailly, peintre architecte dans l'Europe des Lumières (Paris: CNMHS, 1979), 49-51; Daniel Rabreau, Le théâtre de l'Odéon. Du monument de la Nation au théâtre de l'Europe: naissance du monument de loisir urbain au XVIIIe siècle (Paris: Belin, 2007).

17 Christian Hottin, 'L'enseignement: les amphithéâtres', Universités et grandes écoles à Paris. Les palais de la science, ed. by Christian Hottin (Paris: Action artistique de la ville de Paris, 1999), 45-51.

18 Christian Hottin, 'Retour sur un patrimoine parisien méconnu: les espaces de transmission du savoir à l'époque moderne', In Situ, 17 (2011), http://insitu.revues.org/1069 [accessed 14.02.2018]. 
between 1770 and 1775; the Royal College by Jean-François-Thérèse Chalgrin built between 1773 and 1783; and the project for the École des Ponts et Chaussées designed by Alexandre-Théodore Brongniart in 1786. The old buildings of higher education were designed mostly by unknown architects: we don't know anything about Charles Joubert, the designer of the first anatomical theatre for the surgeons in Paris ${ }^{19}$, but in the late $18^{\text {th }}$ century, these schools were designed by the most famous and fashionable architects of the day: Soufflot who was building the Sainte-Geneviève basilica, the future Pantheon; as well as Gondouin, Chalgrin and Brongniart who were building numerous houses for the aristocracy ${ }^{20}$. The three projects also differ from their predecessors as they were mostly funded by the State and not by private individuals, as eminent as they might have been. Another essential difference was the reduced religious nature of each institution, which was a clear sign of the secularisation of knowledge in the Age of Enlightenment. At the Sorbonne, or at the Collège des Quatre-Nations, the chapel stood at the centre of the ensemble, serving both as a place of worship and as a mausoleum for the benefactor. At the Law Schools, the ensemble does not include a chapel as it faces the new Church of Sainte-Geneviève. But at the Royal College, which is not close to any places of worship, there is no space reserved for religious gatherings. At the centre of the School of Surgery, instead of a chapel, one finds the amphitheatre behind a large portico with six giant Corinthian columns. It is visible from the street through an Ionic colonnade supporting the library. The chapel itself is a small non-descript room that the architect Gondouin placed to the right of the colonnade. In the central axis, the chapel has been replaced by the lecture hall, the main teaching space. In the project for the Ponts et Chaussées, the main civil engineering school, inspired by the School of Surgery building, Brongniart organised his ensemble around a vast room devoted to the distribution of prizes. Even when it is present, the space devoted to religious gatherings has disappeared from the monumental representation. This is strikingly

19 Pierre-Louis Laget, 'Le premier amphithéâtre d'anatomie de la communauté des chirurgiens de Paris', Chirurgie, 124 (1999), 686.

20 Alexandre-Théodore Brongniart 1739-1813: architecture et décor (Paris: Musée Carnavalet, 1986); Jacques-Germain Soufflot ou l'architecture régénérée (1713-1780), ed. by Claire Ollagnier (Paris: Picard, 2016); Chalgrin et son temps: architectes et architecture de l'Ancien Régime à la Révolution, ed. by Basile Baudez, Dominique Massounie (Bordeaux: Blake \& Co, 2016). 
different from the proposal for an urban college made by the winner of the Grand Prix in the 1764 competition organised by the Royal Academy of Architecture. Even though the religious symbols have disappeared from the ornamentation of the facades, as we can see from the plan, the chapel still occupies the centre of the ensemble.

These four projects demonstrate another striking difference with the traditional buildings devoted to higher education: the spaces dedicated to private lodgings tended to be less important. At the old Sorbonne, the majority of the buildings were comprised of apartments for the 36 doctors who formed the teaching faculty. At the Law Schools, Soufflot designed only four apartments for the main professors. At the School of Surgery, there are apartments for the administrators and librarians, but at the Royal College by Chalgrin only nine apartments for the most senior professors of the institution are included. The apartment has become a bonus, a privilege instead of being the norm in a common space shared by a community. The principal spaces are devoted to education, instead of communal living or religious gatherings. And an increasing specialisation of the rooms has occurred. The oldest of these specific spaces is the library, which is present on the plans of all the projects under examination. But specific new rooms have appeared. At the Royal College, Chalgrin designed an anatomical and chemistry theatre and several laboratories. For his project for the École des Ponts et Chaussées, Brongniart designed a central circular hall, surrounded by classrooms, workshops, and rooms for storing pedagogical materials. The latter are located on either side of the entrance, in order to be more easily accessible to outside visitors, thereby clearly linking his project with the programme of the museum. All the projects shared common stylistic features: the sobriety of the facades, absence of projections, limited use of orders, and very little ornamentation. From now on, higher education was seen as equivalent to efficiency, austerity, and economy.

In the summer of 1792, during the first months after the proclamation of the Republic, almost all the former French institutions of higher education were closed, only to be reopened soon after. Most of them reoccupied their former buildings: the law faculty in the Soufflot building, medicine in the Gondouin palace, faculties of theology, letters and sciences in the Sorbonne. However, from this time forward, all forms of public education would become independent of the Church, secularised and administrated by the 
State. New institutions were housed in former aristocratic houses: the École des Ponts et Chaussées in the hôtel Carnavalet, the École des Mines in the hôtel de Vendôme in 1815, the École des Langues orientales vivantes (School of Eastern Languages) in the hôtel de Bracqueville, the École Centrale, which trained secondary teachers, in the hôtel de Juignié in 1829. ${ }^{21}$ This does not mean that the university palace disappeared from the thinking of the architects. During the Empire, an intense debate was incited by the project calling for a palace for the university. In an imperial decree on 17 March 1808, Napoleon reorganised the Imperial University. This new organisation, both centralised and highly hierarchised, encompassed all levels of education from elementary to higher education, which consisted of five faculties: three academics (theology, letters and sciences), and two professional colleges (medicine and law). Napoleon put Bernard Poyet, the architect of the National Assembly, in charge of finding a location for a palace for the university as part of a vast program of renovation in the western part of Paris, which was organised around the future palace for the King of Rome, the heir to the imperial throne. ${ }^{22}$ The university building was supposed to occupy a central location between the Imperial Archives, which was to be designed by Jacques Cellerier, and the Palace of Fine Arts also designed by Poyet. In a project designed in 1812, the university and fine arts palace were combined in a single structure. Poyet created four courtyards, each devoted to a different institution: Fine Arts, University, École Normale for school teachers, and Maison des Emérites for retired professors. The chapel totally disappeared from the overall programme and the centre of the ensemble was occupied by the prize distribution hall. The lecture hall became semicircular. A year earlier in 1811, the École des Beaux-Arts, which combined the former fine arts academies of the Ancien Régime, had announced a Grand Prix for the design of a palace for the university; and the winning design by Jean-Louis Provost was derivative of Gondouin's School of Surgery designed fifty years earlier ${ }^{23}$. The designs by both Poyet and Provost feature non-

21 Universités et grandes écoles à Paris. Les palais de la science, ed. by Christian Hottin (Paris: Action artistique de la ville de Paris, 1999).

22 Christian Hottin, Les Sorbonne: figures de l'architecture universitaire à Paris (Paris: Publications de la Sorbonne, 2015), 72-78.

23 Jean-Louis Provost, Design for an Imperial University. Academic Great Prize (1811). École nationale supérieure des Beaux-Arts, PRA 134. 
descript facades, bare walls, and large porticos topped by classical pediments, or large colonnades. Nothing indicates the function of the building to the passersby. The university has yet to find its own architectural idiom.

Since the introduction of the university as an institution in France came late, it did not benefit from the redefinition of the architectural type based on $18^{\text {th }}$ century theory, and the concept of convenience and character, the adequacy of the form to its function and the social rank of its owner as defined by Jacques-François Blondel, the leading professor and theoretician of architecture in France. Its main feature, the lecture hall, is based on the first modern secular space for higher education - the surgeon's dissection hall. However, the universities are the successors of medieval colleges, and once they were disconnected from the Church, they lost their only proper exterior characteristics, as a transition between a private house and religious building. This left them characterless and non-descript, and architects are still struggling with this absence of architectural tradition today.

Basile Baudez: The University: An Architectural Type?

Keywords: Parisian universities; Middle Ages; Enlightenment; University of Sorbonne; architecture; Jacques-Germain Soufflot; Jean-François-Thérèse Chalgrin; Alexandre-Théodore Brongniart

Basile Baudez is an Assistant Professor of Architectural History in the Art and Archaeology Department at Princeton University. Before 2018 he was Assistant Professor of Architectural History at the Paris-Sorbonne University (Paris IV). Baudez has also served as Visiting Professor at the University of Pennsylvania and at the Pratt Institute. His research focuses on $18^{\text {th }}$ and $19^{\text {th }}$ century European architectural history and especially the relationship between architects and politics, the role of the engineers in Europe and 
architectural representation. He published his PhD thesis (2006, École Pratique des hautes Études, Paris) entitled Architecture et Tradition Académique au Siècle des Lumières in 2012. His recent books are Chalgrin. Architectes et Architecture entre l'Ancien Régime et l'Empire (2016) with D. Massounie, A Civic Utopia: Architecture and the City in France 17651837 with N. Olsberg (2016). In process: Inessential Colors: A History of Color in Architectural Representation in Early Modern Europe. 